British \& Irish Botany 1(3): 185-201, 2019

\title{
Japanese Rose (Rosa rugosa): its invasion and colonisation of the Sefton Coast, north Merseyside, UK
}

\author{
Philip H. Smith*, Ben Deed \\ 9 Hayward Court, Watchyard Lane, Formby, Liverpool L37 3QP
}

*Corresponding author: Philip Smith: philsmith1941@tiscali.co.uk

This pdf constitutes the Version of Record published on $13^{\text {th }}$ August 2019

\begin{abstract}
A spiny shrub native to north-west Pacific coasts, Rosa rugosa Thunb. (Japanese Rose) was introduced into Britain in the $19^{\text {th }}$ century as a garden plant. It has since become a well-established and widespread naturalised alien, especially on sand-dunes, shingle beaches and other dry coastal habitats. The plant is also considered invasive on coasts of many other countries in Northwest Europe. Mounting concern about its recent spread on the internationally important sanddune system of the Sefton Coast, north Merseyside, led to a volunteer survey being organised in 2014, involving 47 participants. They searched most of the 27 $\mathrm{km}$-long coastal zone, recording almost 500 patches with a total area of nearly 6 ha. $R$. rugosa occurred especially on younger calcareous dunes (soil pH $5.6-$ 8.2) near the sea and close to roads and human habitation. Few patches were found on older, more acidic duneland, or on a $5 \mathrm{~km}$ erosion front around Formby Point. This pattern of occurrence accords with that reported elsewhere for $R$. rugosa, indicating that the sea is implicated in the dispersion of propagules and that the species also establishes from anthropogenic sources, including ornamental plantings. It is concluded that the plant is a threat to dune habitats and species on the Sefton Coast. Control measures are discussed and the early stages of patch removal are described.
\end{abstract}

Keywords: Dispersal; introduction; management; non-native; sand dune.

\section{Introduction}

Origin and geographical distribution

Rosa rugosa Thunb. (Japanese Rose) is a deciduous, spiny, strongly suckering shrub native to northern Japan, north-east China and the Russian far-east. Having large, attractive, pink or white flowers and large red hips, it was first introduced to Britain in 1796 but was not successfully grown as a garden and landscape ornamental until after its re-introduction in 1845. The shrub was first recorded in the wild in Cumberland in 1927 (Maskew, 2002), since when it has 
become a well-established naturalised alien throughout Britain and in parts of Ireland. The Botanical Society of Britain \& Ireland (BSBI) Maps Project shows an exponential rate of spread (Fig. 1), though some of this increase is thought to be due to better recording (Maskew, 2002). By 2014, R. rugosa had been observed in 1325 hectads (10 x $10 \mathrm{~km}$ UK National Grid squares) in Britain and Ireland. The plant is also naturalised in large parts of northwest and central Europe, being considered invasive along coasts of the North Atlantic, North Sea and Baltic, including the Netherlands, Germany, Denmark, Norway, Sweden and Lithuania (Bruun, 2005; Weidema, 2006). Infestations have also been reported in dunes on the Atlantic coasts of Canada (Hill et al. 2010).

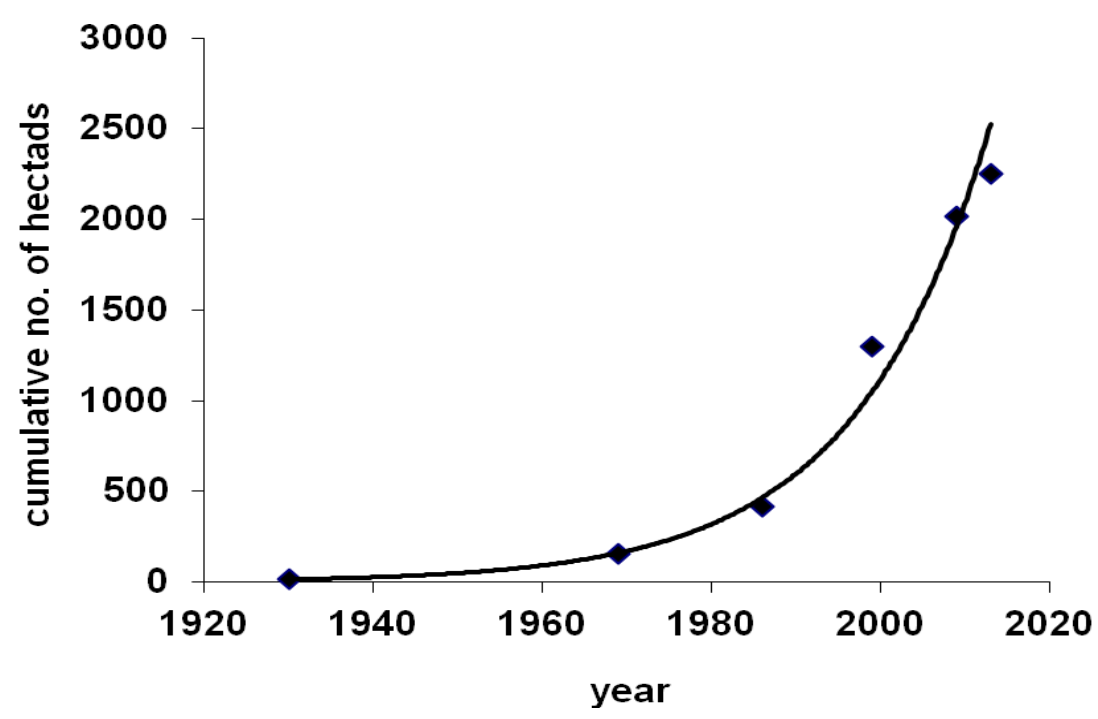

Figure 1. Rate of colonisation of Britain \& Ireland by Rosa rugosa based on BSBI hectad records. The fitted line is an exponential.

\section{Biology}

In Britain, there appear to be no limitations to growth of $R$. rugosa from southern England to Shetland but the shrub occurs especially on sand dunes, shingle beaches and other dry coastal habitats. It grows less vigorously inland and is rarely found in the uplands, being largely absent from strongly acid soils (Bruun, 2005).

Dense stands can form by suckering on both mobile dunes dominated by Ammophila arenaria (Marram), fixed dunes and dune grasslands (Fig. 2). The plant tolerates and seems to benefit from a sand covering of up to $30 \mathrm{~cm}$ per annum. It is also resistant to frost, heat, drought and salinity, even spreading along salt-treated roads in Scandinavia (Bruun, 2005). $R$. rugosa is largely excluded from pastures but, once present, it resists grazing, only seedling and juvenile stages being susceptible (Weidema, 2006). Pollination is mainly by bees, especially bumblebees (Bombus) and the bushes produce abundant hips whose seeds are dispersed by a variety of birds, including thrushes ( Turdus) and by 
seawater. Both hips and achenes are buoyant and can float for several weeks, occurrences on uninhabited Scandinavian islands being thought to be due to maritime dispersal (Weidema, 2006). However, once established the main mechanism of spread is through vegetative reproduction via suckers (Bruun, 2005; Weidema, 2006).

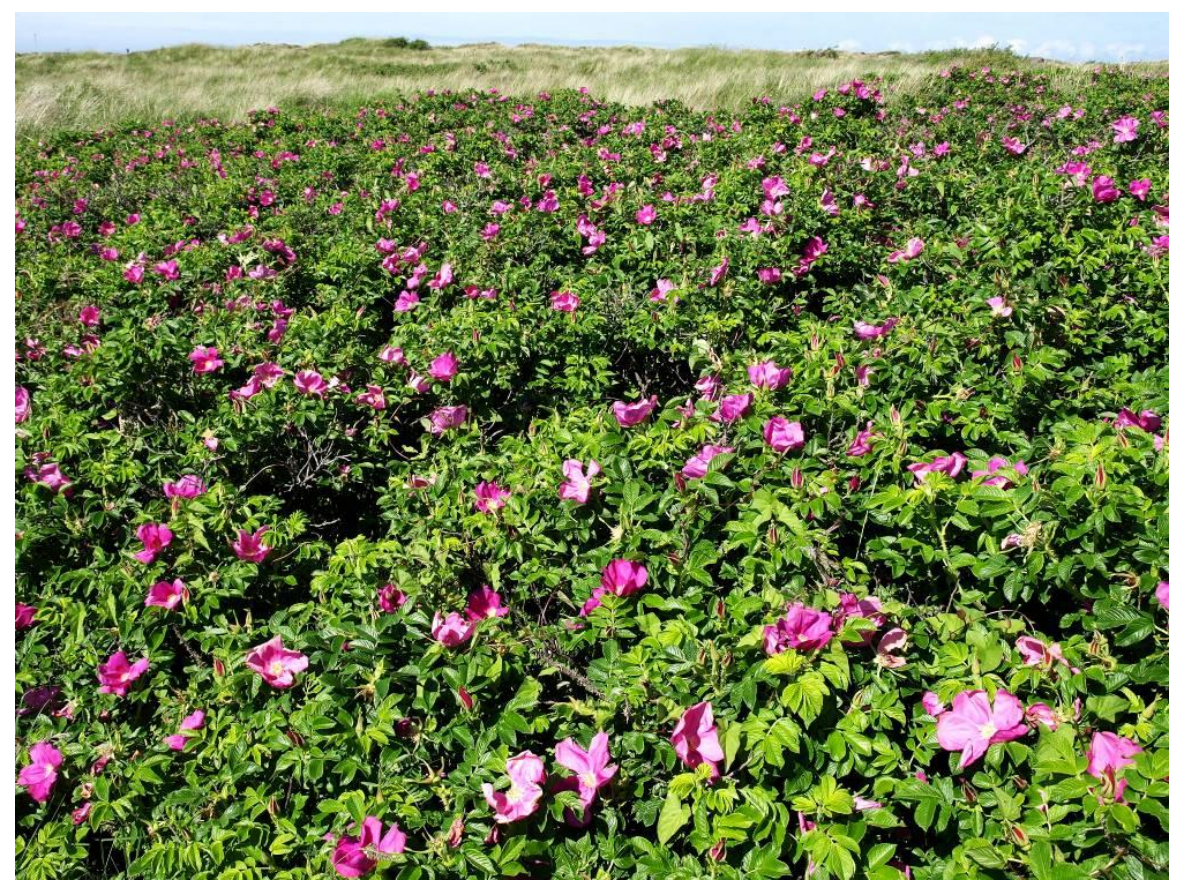

Figure 2. Large patch of $\boldsymbol{R}$. rugosa, Hightown sand dunes, June 2008

\section{Impacts}

$R$. rugosa can form impenetrable thickets of up to $100 \%$ cover in all dry dune habitats, excluding almost all other plants and the animals associated with them. It even replaces typical duneland shrubs, such as Salix repens (Creeping Willow) and Rosa spinosissima (Burnet Rose). This strong reduction in species diversity is caused by shading and represents a serious conservation problem (Isermann, 2008). In addition to ecological impacts, the plant can be a nuisance to landowners and coastal visitors because the thorny thickets hinder walking and sun-bathing. Such is the prevalence of this species that, in some places, it is regarded as a typical component of the landscape. Thus, the plant is known on the German island of Sylt as the "Sylt Rose" and may even appear on tourist brochures (Weidema, 2006).

\section{Occurrence on the Sefton Coast}

The Sefton Coast in North Merseyside, UK includes extensive saltmarshes at the mouth of the Ribble Estuary and the largest sand dune system in England (2100ha). The international importance of these features for nature conservation is recognised by European Special Area of Conservation and Special Protection 
Area status, as well as RAMSAR designation, while most of the dune system and estuary lie within Sites of Special Scientific Interest. There are also three National Nature Reserves (NNR) and two Local Nature Reserves (LNR).

The widespread presence of $R$. rugosa on the Sefton Coast is a relatively recent phenomenon. The earliest records were in 1927 (the same year as the first British record in a wild state), when J.D. Massey identified the plant in sandhills at Formby and a pine plantation at Freshfield (D. P. Earl, personal communication, 2013). Green (1933) cited this 1927 observation while Savidge et al. (1963) described the plant as "rare", adding only sightings in 1961 at Freshfield and Ainsdale. The comprehensive National Vegetation Classification (NVC) of the dune system by Edmondson et al. (1988/89) included only three records of $R$. rugosa. However, a second NVC survey carried out in 2003/04 found 13 patches dominated by the plant, together with several other occurrences in stands of mixed scrub (Gateley \& Michell, 2004). These surveys divided the Sefton dunes into 23 divisions, three of which contained $R$. rugosa in $1988 / 89$, increasing to nine in 2003/04. Edmondson (2010) suggested it may have originated from landscape plantings around carparks and amenity areas, as well as escaping from gardens.

Currently, $R$. rugosa occurs sporadically throughout most of the dune system, having been recorded in all the coastal tetrads ( $2 \times 2 \mathrm{~km}$ squares) and most of the monads (1 km squares) (D.P. Earl, personal communication, 2014). To the north of the dune system, $R$. rugosa was also known to be present on upper saltmarsh habitat and reclaimed grazing-marsh managed as the Marshside Nature Reserve by the Royal Society for the Protection of Birds. Large spreading patches of the plant have long been present at Altcar Training Camp, Birkdale Sandhills LNR and at Hightown, where it has colonised a botanically interesting "shingle" beach derived from brick-rubble eroding from a tipped embankment (Smith, 2010). With concern mounting about the shrub's recent increase, it was thought opportune to organise an investigation into its distribution and extent, with the aim of collecting information that could be used in the formulation of a management strategy. Accordingly, it was decided to recruit a team of volunteers for a coastwide survey of $R$. rugosa.

\section{Methods}

Early in 2014, 47 volunteers, including the authors, were recruited for the survey. A survey protocol outlined field work methods: to record the position (UK National Grid Reference), area in square metres (derived from length $\times$ breadth) and maximum height $(\mathrm{cm})$ of each patch. In addition, an assessment was made of the general habitat type: fore-dune, fixed-dune, shingle (Hightown only), dune-scrub, woodland edge, old field, etc.

Surface soil samples were taken at 48 sites supporting $R$. rugosa, $\mathrm{pH}$ being determined using a Lutron $\mathrm{PH}-212$ soil pH meter buffered at $\mathrm{pH} 4$ and 7. The distances of these locations from the coastline were determined by reference to aerial photographs and the 'ruler' tool on Google Earth. 
As far as possible, volunteers were organised to work in pairs or small teams, each being allocated one of 22 units that could reasonably be searched in a small number of half-day sessions. Maps derived from aerial photographs were provided, defining search areas and aiding navigation in the field. They covered the $27 \mathrm{~km}$ coastal zone from Seaforth in the south to Crossens in the north, including the whole of the dune-system, with the exception of the golf courses, these being excluded for practical and safety reasons. Mapinfo GIS was used to calculate the search area of each mapped survey unit. A lone working procedure, based on a Natural England document was circulated to the few individuals who opted to work on their own. In addition, a risk assessment proforma was prepared and sent to all volunteers. Finally, each team was provided with survey forms to be completed in the field and returned to the organisers. Most fieldwork took place between June and August 2014, patches of $R$. rugosa being easier to locate while in flower.

\section{Results}

Distribution and numbers

Within the search area of about 2000 ha, 496 patches were recorded covering $58158 \mathrm{~m}^{2}$ (5.8 ha) with an average area of $117 \mathrm{~m}^{2}$ (Table 1; Fig. 3). Most plants were pink-flowered (Fig. 2) but white flowered specimens were also well represented. Five individuals were thought to be referable to Rosa 'Hollandica', a hybrid between $R$. rugosa and another unknown parent (Bruun, 2005). The largest number of patches (89) was found in unit 5, Birkdale frontal dunes (2), which extends south from Selworthy Road for about $1.5 \mathrm{~km}$. However, by far the greatest area of $R$. rugosa occurred in unit 17: Altcar Training Camp, where 54 patches covered $16,315 \mathrm{~m}^{2}$ (1.6 ha), with a mean area of $302 \mathrm{~m}^{2}$ (median 110 $\mathrm{m}^{2}$ ). Here, the largest individual patch was $460 \mathrm{~m}$ long, extending over an estimated $3260 \mathrm{~m}^{2}$. Median patch area varied greatly from $403 \mathrm{~m}^{2}$ at unit 7: Birkdale LNR (N) to only $0.5 \mathrm{~m}^{2}$ at unit 14: Lifeboat Road, Formby, while all units showed a wide range of patch sizes (Table 1). Maximum patch height ranged from $178 \mathrm{~cm}$ at Marshside to $58 \mathrm{~cm}$ at Ainsdale LNR, though patches averaged about $100 \mathrm{~cm}$ tall overall (median $125 \mathrm{~cm}$ ).

Table 1. Summary of Rosa rugosa patch data for each survey unit (north to south).

\begin{tabular}{|c|c|c|c|c|c|}
\hline $\begin{array}{l}\text { Unit } \\
\text { No. }\end{array}$ & Locality & $\begin{array}{c}\text { No. of } \\
\text { patches }\end{array}$ & $\begin{array}{l}\text { Total } \\
\text { Area } \\
\left(\mathrm{m}^{2}\right)\end{array}$ & $\begin{array}{c}\text { Median } \\
\text { Area }\left(\mathbf{m}^{2}\right) \\
\text { Range }\end{array}$ & $\begin{array}{c}\text { Median } \\
\text { Height } \\
\text { (cm) } \\
\text { Range }\end{array}$ \\
\hline 1 & Marshside, Southport & 40 & 689 & $\begin{array}{c}8.5 \\
1-162\end{array}$ & $\begin{array}{c}200 \\
100-300\end{array}$ \\
\hline 2 & Southport Marine Lake & 7 & 198 & $\begin{array}{c}12 \\
0.1-80\end{array}$ & $\begin{array}{c}90 \\
20-170\end{array}$ \\
\hline
\end{tabular}




\begin{tabular}{|c|c|c|c|c|c|}
\hline 3 & $\begin{array}{l}\text { Queen's Jubilee Nature } \\
\text { Trail, Southport }\end{array}$ & 18 & 3478 & $\begin{array}{c}100 \\
4-900\end{array}$ & $\begin{array}{c}150 \\
30-250\end{array}$ \\
\hline 4 & $\begin{array}{l}\text { Birkdale frontal dunes } \\
\text { (1) }\end{array}$ & 18 & 2745 & $\begin{array}{c}19 \\
2.5-1406\end{array}$ & $\begin{array}{c}100 \\
30-170\end{array}$ \\
\hline 5 & $\begin{array}{l}\text { Birkdale frontal dunes } \\
\text { (2) }\end{array}$ & 89 & 3963 & $\begin{array}{c}9 \\
0.1-460\end{array}$ & $\begin{array}{c}85 \\
40-200\end{array}$ \\
\hline $6 a$ & $\begin{array}{l}\text { Sands Lake area, } \\
\text { Ainsdale }\end{array}$ & 9 & 1965 & $\begin{array}{c}55 \\
1-950\end{array}$ & $\begin{array}{c}150 \\
50-250\end{array}$ \\
\hline $6 b$ & $\begin{array}{l}\text { Birkdale frontal dunes } \\
\text { (3) }\end{array}$ & 68 & 7112 & $\begin{array}{c}27 \\
0.2-1258\end{array}$ & $\begin{array}{c}110 \\
40-200\end{array}$ \\
\hline 7 & $\begin{array}{l}\text { Birkdale Sandhills LNR } \\
\text { (N) }\end{array}$ & 4 & 1651 & $\begin{array}{c}403 \\
72-774\end{array}$ & $\begin{array}{c}150 \\
100-150\end{array}$ \\
\hline 8 & $\begin{array}{l}\text { Birkdale Sandhills LNR } \\
\text { (S) }\end{array}$ & 20 & 7633 & $\begin{array}{c}269 \\
18-1320\end{array}$ & $\begin{array}{c}132 \\
40-200\end{array}$ \\
\hline 9 & $\begin{array}{l}\text { Falklands Way \& } \\
\text { Kenilworth dunes }\end{array}$ & 24 & 2080 & $\begin{array}{c}23 \\
1-700\end{array}$ & $\begin{array}{c}110 \\
30-200\end{array}$ \\
\hline $10 a$ & $\begin{array}{l}\text { Ainsdale Sandhills LNR } \\
\text { (1) }\end{array}$ & 8 & 415 & $\begin{array}{c}2.4 \\
0.4-468\end{array}$ & $\begin{array}{c}80 \\
40-175\end{array}$ \\
\hline $10 \mathrm{~b}$ & $\begin{array}{l}\text { Ainsdale Sandhills LNR } \\
\text { (2) }\end{array}$ & 8 & 825 & $\begin{array}{c}81 \\
1.5-286\end{array}$ & $\begin{array}{c}50 \\
20-100\end{array}$ \\
\hline 11 & $\begin{array}{l}\text { Ainsdale Sand Dunes } \\
\text { NNR (1) }\end{array}$ & 3 & 222 & $\begin{array}{c}100 \\
2-120\end{array}$ & $\begin{array}{c}90 \\
50-125\end{array}$ \\
\hline 12 & $\begin{array}{l}\text { Ainsdale Sand Dunes } \\
\text { NNR (2) }\end{array}$ & 1 & 78 & $\begin{array}{l}78 \\
-\end{array}$ & 60 \\
\hline 13 & $\begin{array}{l}\text { National Trust, Formby } \\
\text { Point }\end{array}$ & 2 & 35 & $\begin{array}{c}18 \\
5-30\end{array}$ & $\begin{array}{c}125 \\
50-200\end{array}$ \\
\hline 14 & $\begin{array}{l}\text { Lifeboat Road dunes, } \\
\text { Formby }\end{array}$ & 3 & 25 & $\begin{array}{c}0.5 \\
0.2-24\end{array}$ & $\begin{array}{c}90 \\
70-220\end{array}$ \\
\hline 15 & Ravenmeols Hills LNR & 18 & 1567 & $\begin{array}{c}27 \\
1-468\end{array}$ & $\begin{array}{c}50 \\
50-300\end{array}$ \\
\hline 16 & Cabin Hill NNR & 17 & 150 & $\begin{array}{c}1.6 \\
0.1-31 \\
\end{array}$ & $\begin{array}{c}54 \\
44-110\end{array}$ \\
\hline 17 & Altcar Training Camp & 54 & 16315 & $\begin{array}{c}110 \\
1-3260\end{array}$ & $\begin{array}{c}70 \\
30-150\end{array}$ \\
\hline 18 & Hightown dunes & 41 & 3880 & $\begin{array}{c}21 \\
1-455 \\
\end{array}$ & $\begin{array}{c}50 \\
30-180 \\
\end{array}$ \\
\hline 19 & $\begin{array}{l}\text { Hall Road, } \\
\text { Blundellsands }\end{array}$ & 29 & 2405 & $\begin{array}{c}20 \\
0.75-1280\end{array}$ & $\begin{array}{c}90 \\
30-130\end{array}$ \\
\hline 20 & Crosby \& Seaforth & 15 & 727 & $\begin{array}{c}23 \\
2-251\end{array}$ & $\begin{array}{c}70 \\
20-130\end{array}$ \\
\hline Total & & 496 & 58158 & & \\
\hline
\end{tabular}


It is evident from Table 1 and also the distribution maps (Fig. 3) that the highest numbers and greatest extent of patches were found towards the northern and southern extremities of the coast, especially at Birkdale and Altcar/Hightown, while the central section from Ainsdale to Formby (units 10-14) was much less infested by $R$. rugosa. Furthermore, areas of highest patch concentration seemed to be either in areas near the shore, for example at Marshside, Birkdale, Altcar and Hightown, or close to roads and other built structures, such as at Birkdale LNR (south), Falklands Way, Ainsdale and Hall Road, Blundellsands.
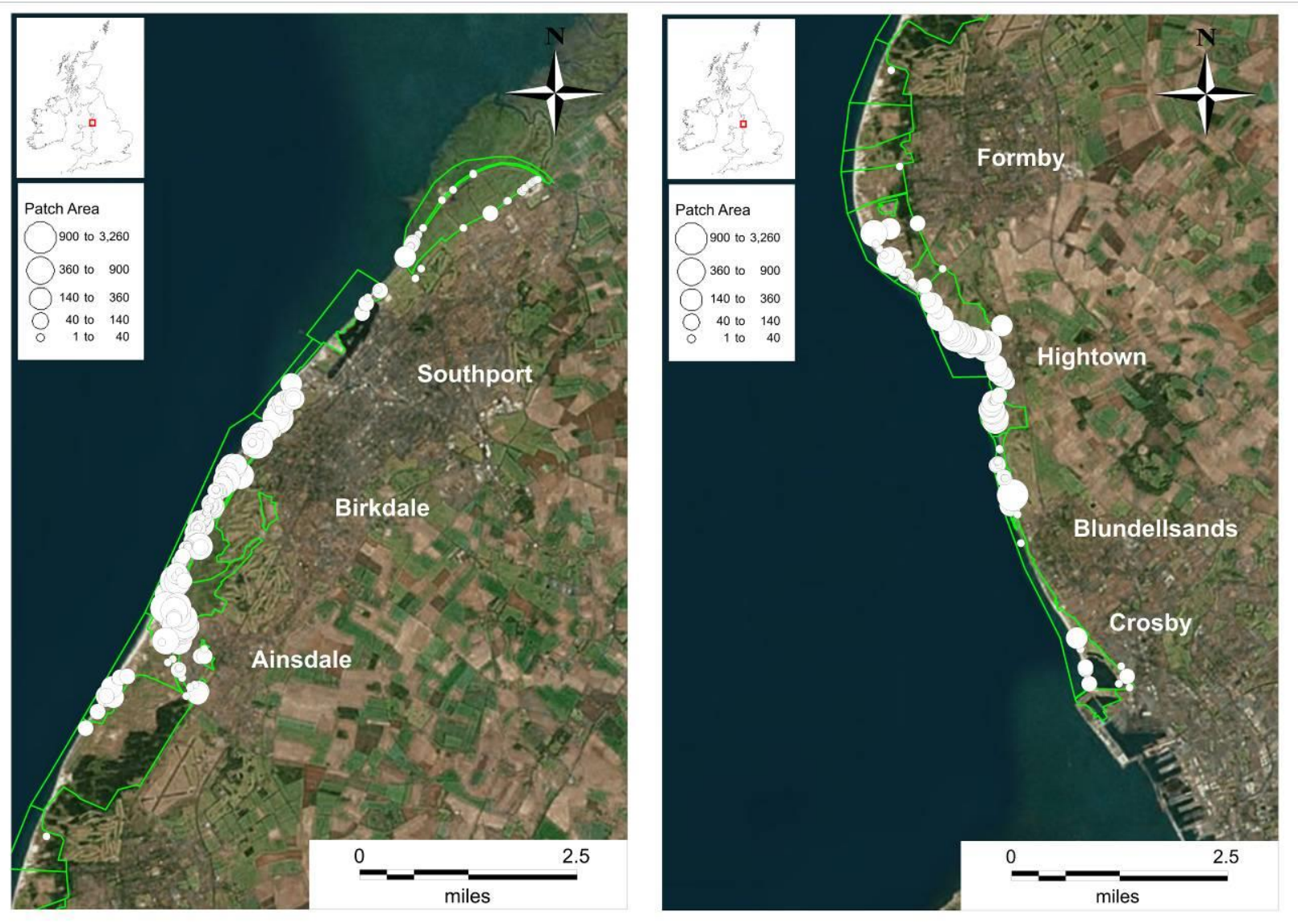

Figure 3. Distribution of Rosa rugosa patches on the north (left) and south (right) Sefton Coast

These findings are reinforced by reference to patch density in the search areas. Table 2 shows that the highest densities were found in the southern part of Birkdale LNR, the Birkdale frontals, Queen's Jubilee Nature Trail, Falklands Way \& Kenilworth Road dunes in the northern sector and at Altcar Training Camp, Hightown dunes and Hall Road in the south. Low densities were associated with Ainsdale NNR, the National Trust and Lifeboat Road dunes along the central section of the coast. 
Table. 2. Density of Rosa rugosa in survey units

\begin{tabular}{|l|l|c|c|c|}
\hline \multicolumn{1}{|c|}{ Unit } & \multicolumn{1}{|c|}{ Location } & $\begin{array}{c}\text { Search } \\
\text { area } \\
\mathbf{( h a )}\end{array}$ & $\begin{array}{c}\text { Bush } \\
\text { area } \\
\mathbf{( m}^{\mathbf{2}} \mathbf{)}\end{array}$ & $\begin{array}{c}\text { Density } \\
\mathbf{m}^{\mathbf{2}} \mathbf{\text { per }} \\
\mathbf{h a}\end{array}$ \\
\hline 1 & Marshside, Southport & 225.7 & 689 & 3.1 \\
\hline 2 & Southport Marine Lake & 85.2 & 198 & 2.3 \\
\hline 3 & $\begin{array}{l}\text { Queen's Jubilee Nature Trail, } \\
\text { Southport }\end{array}$ & 54.4 & 3478 & 63.9 \\
\hline $4,5,6 \mathrm{a}$, & Birkdale frontal dunes & 200.6 & 15785 & 78.7 \\
\hline $6 \mathrm{~b}$ & & 69.1 & 1651 & 23.9 \\
\hline 7 & Birkdale Sandhills LNR (N) & 72.3 & 7633 & 105.6 \\
\hline 8 & Birkdale Sandhills LNR (S) & 27.6 & 2080 & 75.3 \\
\hline 9 & $\begin{array}{l}\text { Falklands Way \& Kenilworth } \\
\text { dunes }\end{array}$ & 125.1 & 1240 & 9.9 \\
\hline $10 \mathrm{a}, 10 \mathrm{~b}$ & Ainsdale Sandhills LNR & 352.5 & 300 & 0.9 \\
\hline 11,12 & Ainsdale Sand Dunes NNR & 223.3 & 35 & 0.2 \\
\hline 13 & National Trust Formby Point & 71.5 & 25 & 0.4 \\
\hline 14 & Lifeboat Road dunes, Formby & 140.3 & 1567 & 11.2 \\
\hline 15 & Ravenmeols Hills LNR & 32.2 & 150 & 4.7 \\
\hline 16 & Cabin Hill NNR & 169.6 & 16315 & 96.2 \\
\hline 17 & Altcar Training Camp & 62.1 & 3880 & 62.5 \\
\hline 18 & Hightown dunes & 33.2 & 2405 & 72.5 \\
\hline 19 & Hall Road, Blundellsands & 175.7 & 727 & 4.1 \\
\hline 20 & Crosby \& Seaforth & 2121 & 58158 & \\
\hline Total & & & & \\
\hline
\end{tabular}

Habitat

The main habitats supporting bushes are listed in Table 3.

Table 3. Main habitats on the Sefton Coast occupied by Rosa rugosa

\begin{tabular}{|l|c|c|}
\hline Habitat & $\begin{array}{l}\text { No. of } \\
\text { bushes }\end{array}$ & $\mathbf{\%}$ \\
\hline Saltmarsh transition & 17 & 4 \\
\hline Shingle/rubble & 26 & 6 \\
\hline Frontal/mobile dune & 14 & 3 \\
\hline Semi-fixed dune & 89 & 21 \\
\hline Fixed dune & 167 & 38 \\
\hline Dune scrub/woodland & 56 & 13 \\
\hline Alder fringe & 65 & 15 \\
\hline Slack & 2 & 0.5 \\
\hline
\end{tabular}


It should be noted that 60 patches $(12 \%)$ were not ascribed a habitat on the recording forms and are therefore excluded from this analysis. Fixed-dunes were the preferred habitat for $R$. rugosa, supporting $38 \%$ of patches, followed by semi-fixed dunes (21\%), while dune-scrub/woodland fringe held $13 \%$ of patches. Habitats little favoured by the plant included mobile dune (3\%) and dune-slack $(0.5 \%)$. The transition between saltmarsh and terrestrial habitat at Marshside on the Ribble Estuary supported $4 \%$ of patches, while $15 \%$ were found on the fringe of Alnus g/utinosa (Alder) woodland along a seepage zone on the eastern edge of Birkdale Green Beach (Fig. 5). A weathered brick rubble embankment between Hall Road and Hightown held $6 \%$ of the patches (Fig. 6).

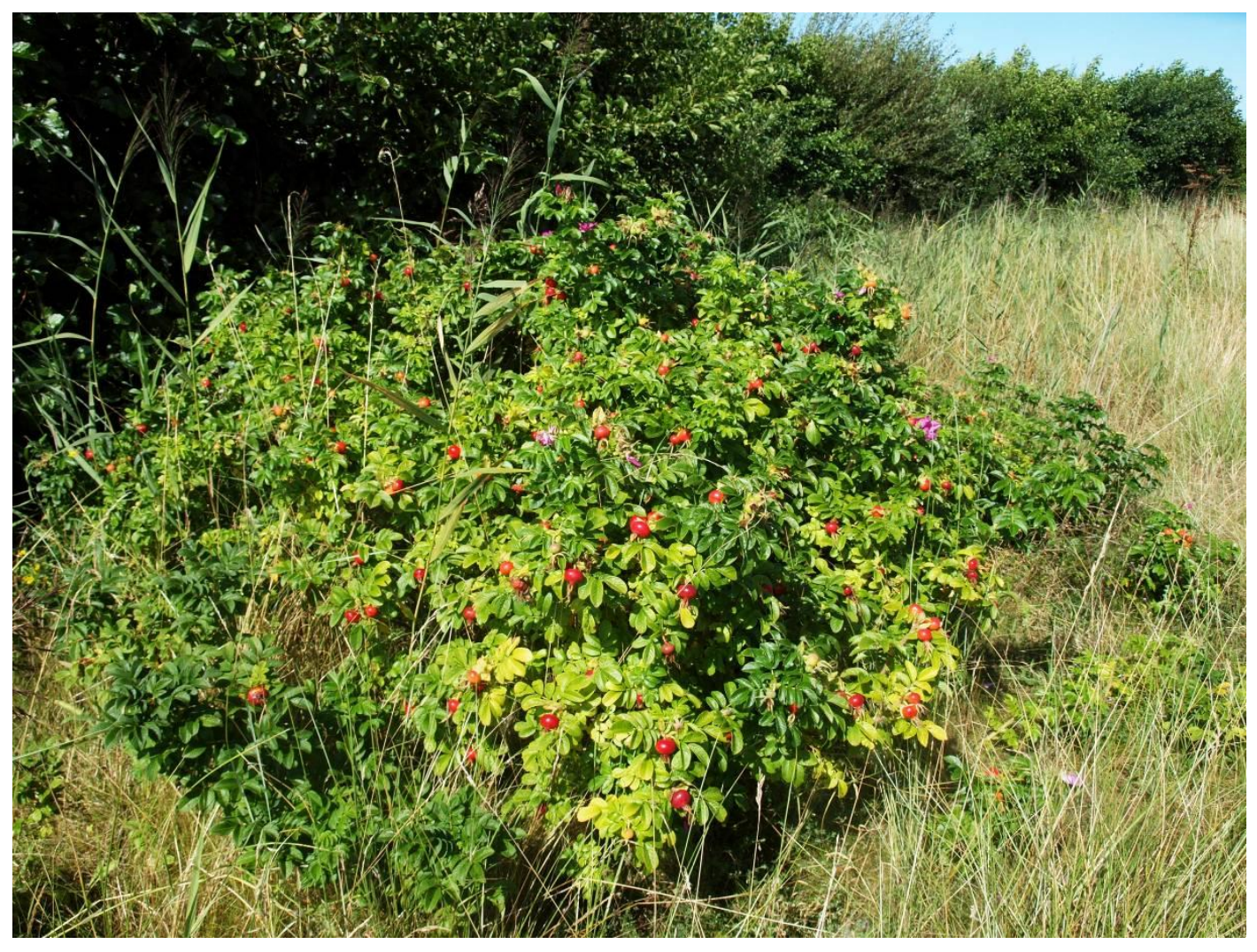

Figure 5. R. rugosa growing with Alnus glutinosa, Birkdale Green Beach, August 2014

Soil $p H$

Forty-eight soil samples from representative sites occupied by $R$. rugosa had a mean pH of 7.2 (median $=7.3$ ), a standard deviation of \pm 0.5 and a range of 5.6-8.2. Fig. 7 shows that soil $\mathrm{pH}$ declines with distance from the shore over the first $250 \mathrm{~m}$, then remains more-or-less constant. 


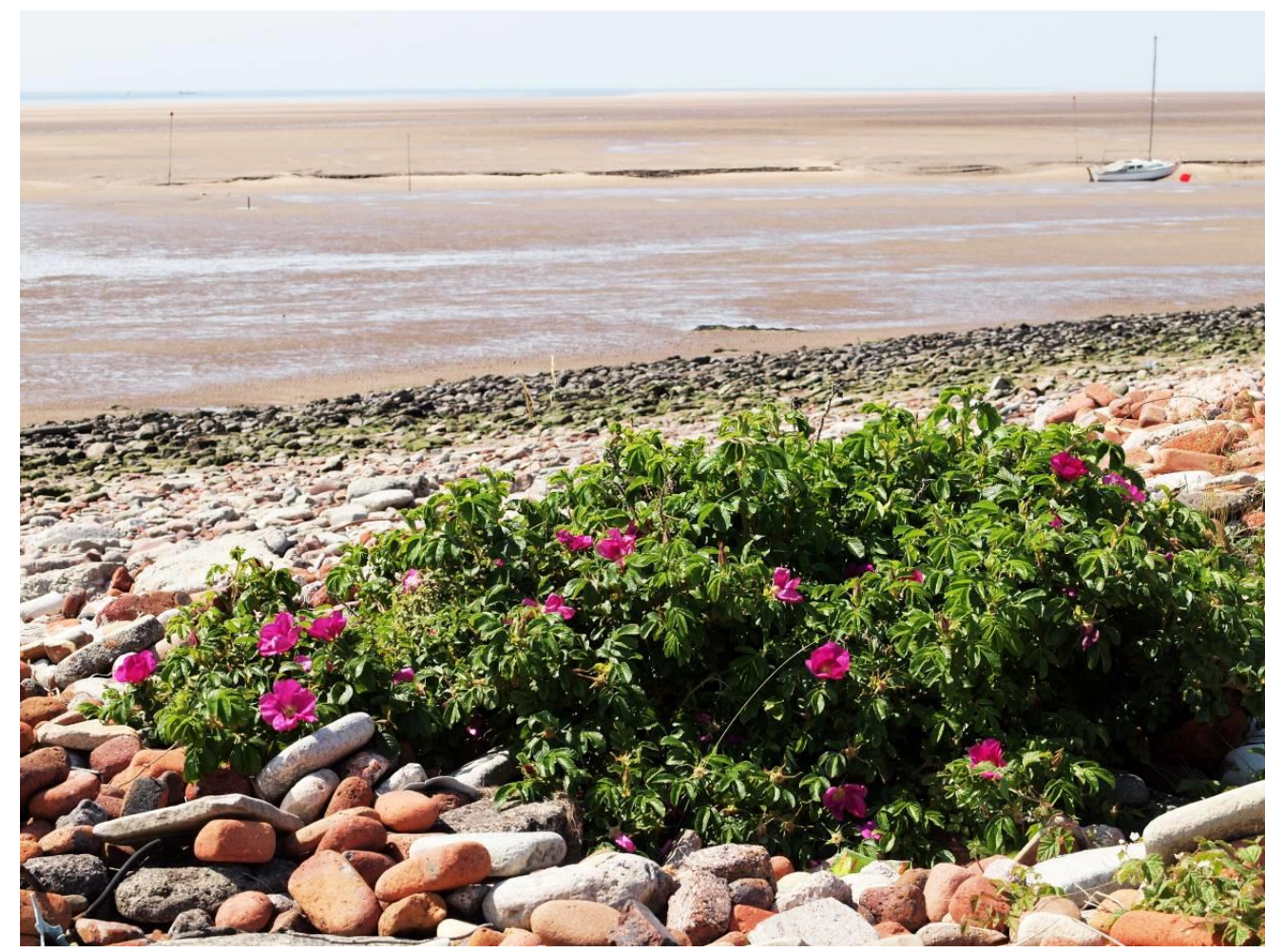

Figure 6. R. rugosa on brick rubble "shingle" at Hightown, June 2015

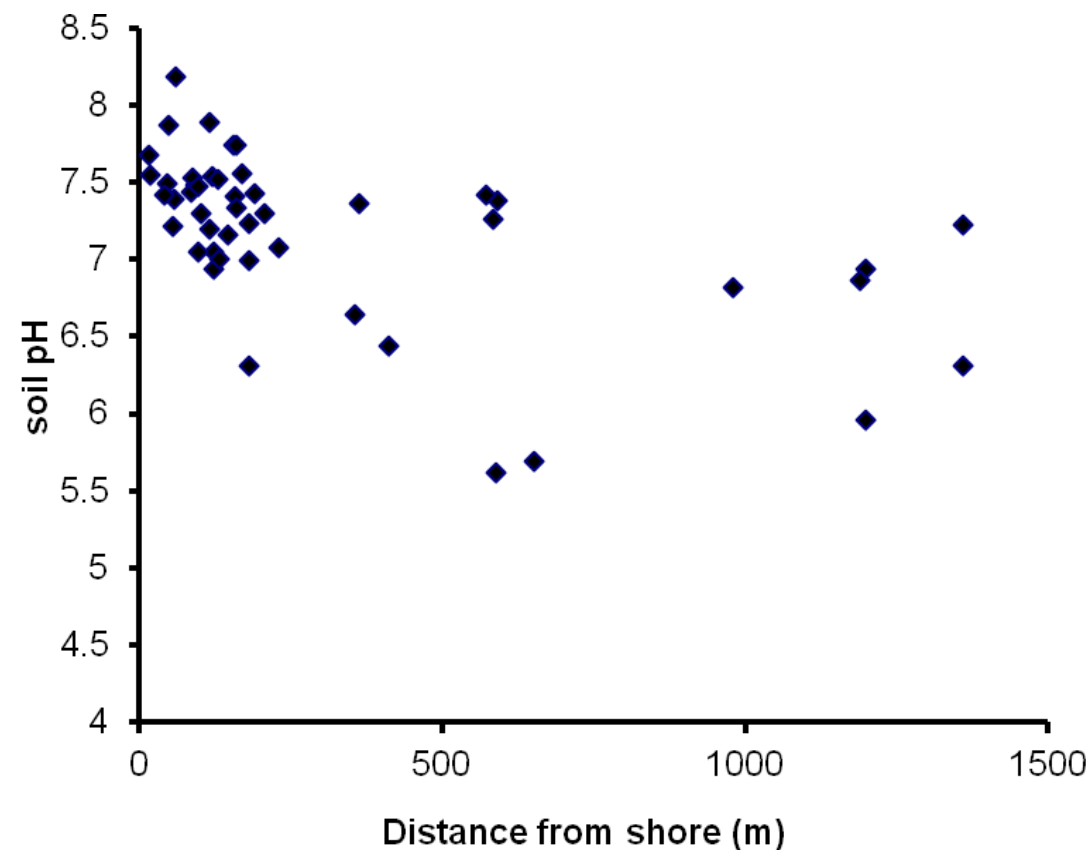

Figure 7. Relation between soil pH and distance from the shore for Sefton sites supporting $R$. rugosa 


\section{Discussion}

The role of a large team of volunteers in the survey was crucial, as to employ professionals would have been prohibitively expensive and time consuming, probably requiring more than one field season. However, partly because of the varied abilities of the participants, collection of supporting ecological information was limited and recommendations for habitat recording were sometimes misconstrued. Another shortcoming was the exclusion of the golf courses which occupy about $25 \%$ of the dune system (Smith, 2009), though $R$. rugosa is not thought to have a strong representation on these land-holdings (personal observations).

Although it was known that $R$. rugosa had become more frequent in recent years, the size of the current population, with around 500 patches covering nearly 6 ha, was unexpected. Of particular interest is the distribution pattern, most patches being concentrated in a fairly narrow zone within about $200 \mathrm{~m}$ of the shore (Fig. 3; Fig. 7). Although a few plants were found up to 1300 $\mathrm{m}$ inland, none was encountered on decalcified acid grasslands and dune heath on the eastern fringes of the duneland. The distribution pattern of $R$. rugosa with most patches in a narrow zone near the shore and few further inland accords with the ancestral habitat of this species in the north-west Pacific. Here, Bruun (2005) found that $R$. rugosa inhabits stabilised dunes, rocky shores, single beaches and meadows, always near the coast and often in a narrow fringe between the sandy beach and dune forest. On continental European North Sea coasts, the shrub is also predominantly associated with yellow-dune vegetation but has also colonised a range of acidic communities, including dune-heath with Empetrum nigrum (Crowberry) (Isermann, 2008).

The pattern of distribution on the Sefton Coast suggests that propagules often arrived by sea. This is also supported by the plant's abundance on a former beach-cleanings tip in the Birkdale frontal dunes, where tidal debris was deposited by the council during the 1970s and 1980s (Smith, 2009). On Birkdale Green Beach, $R$. rugosa is associated with strips of Alnus glutinosa woodland that are thought to have arisen as seeds washed up on former strand-lines (Smith, 2007) (Fig. 5).

A similar survey by Jørgensen \& Kollmann (2009) in northwest Denmark also found patches of $R$. rugosa most abundant in "white-dunes" close to the shore, this habitat having the highest seedling establishment in a related study (Kollmann et al., 2007). Weidema (2006) describes how $R$. rugosa hips can float for up to 40 weeks in both fresh and sea-water, the achenes also having good buoyancy when released from the disintegrating hips. She maintains that, in contrast to other Rosa spp., this plant is well adapted to dispersion by water. Following storm surge damage during the winter of 2013/14, large numbers of $R$. rugosa seedlings were observed on the Hightown shingle beach, having presumably arisen from propagules dispersed by the exceptionally high tides (Fig. 8). 
The relative absence of patches in the central section of the Sefton coast is readily explained by the fact that a $5 \mathrm{~km}$ stretch around Formby Point has been subject to coastal erosion at an average rate of about $4 \mathrm{~m}$ per annum for over 100 years (Smith, 2009). Thus, the frontal dune habitat in which $R$. rugosa would normally become established has been regularly washed away.

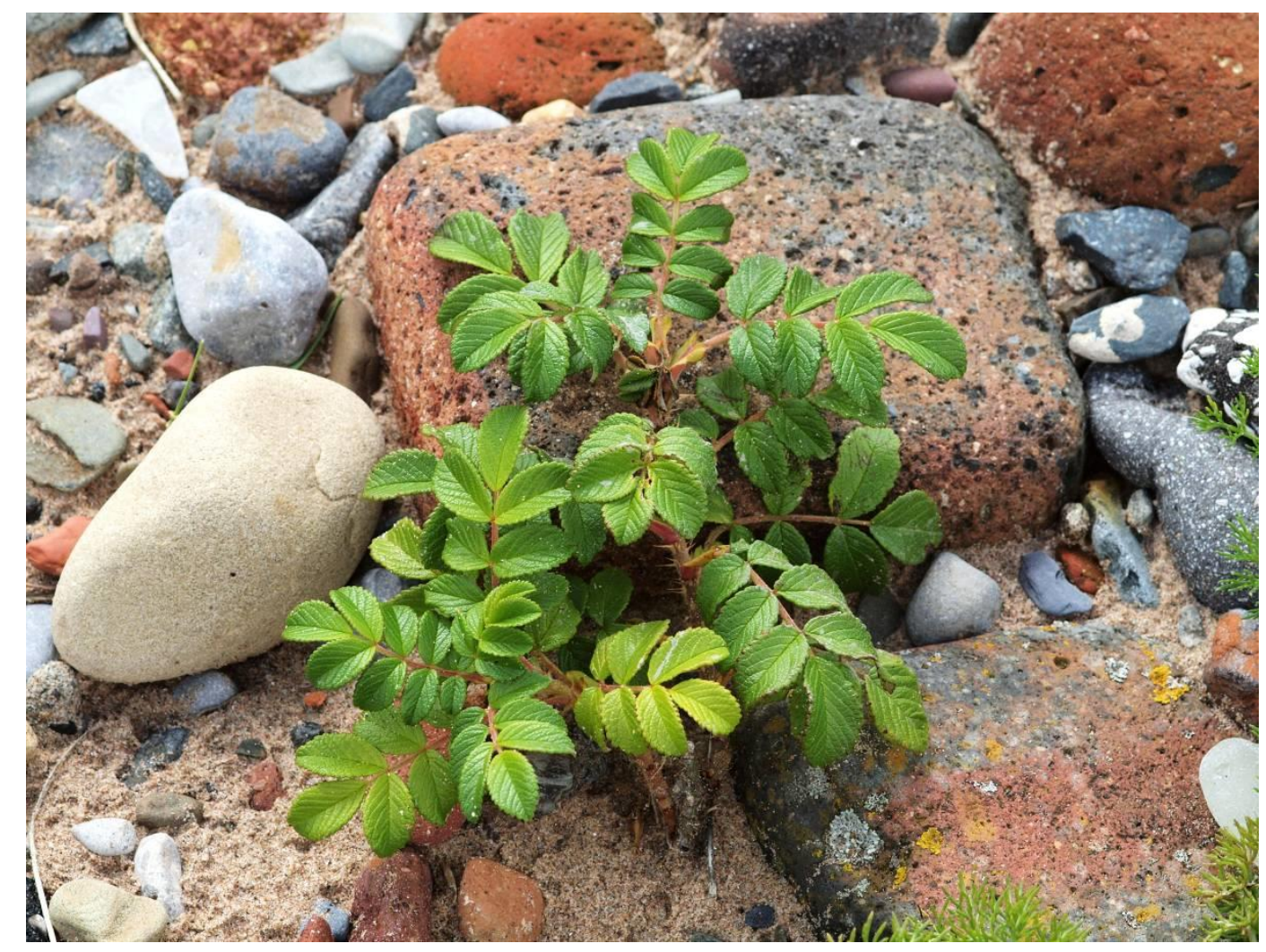

Figure 8. Seedling R. rugosa on Hightown brick rubble "shingle", July 2014, following a storm-surge

Jørgensen \& Kollmann's (2009) study showed that the distribution of $R$. rugosa in Denmark was positively correlated with roads, tracks and houses. This suggests that the plant's occurrence is partly determined by anthropogenic factors, such as ornamental plantings. They also argue that sites near habitations are likely to have higher nutrient loads, leading to improved establishment and growth. Their findings accord with occurrences on the Sefton Coast, where many large patches of $R$. rugosa were found on road-sides, for example at Birkdale, Ainsdale and Falklands Way (Fig. 9). The only patches recorded at the Formby Point National Trust estate were associated with a caravan site, the recorders finding documentation to show that these were part of a 1982 planting scheme (D. Thompson, personal communication, 2014). 


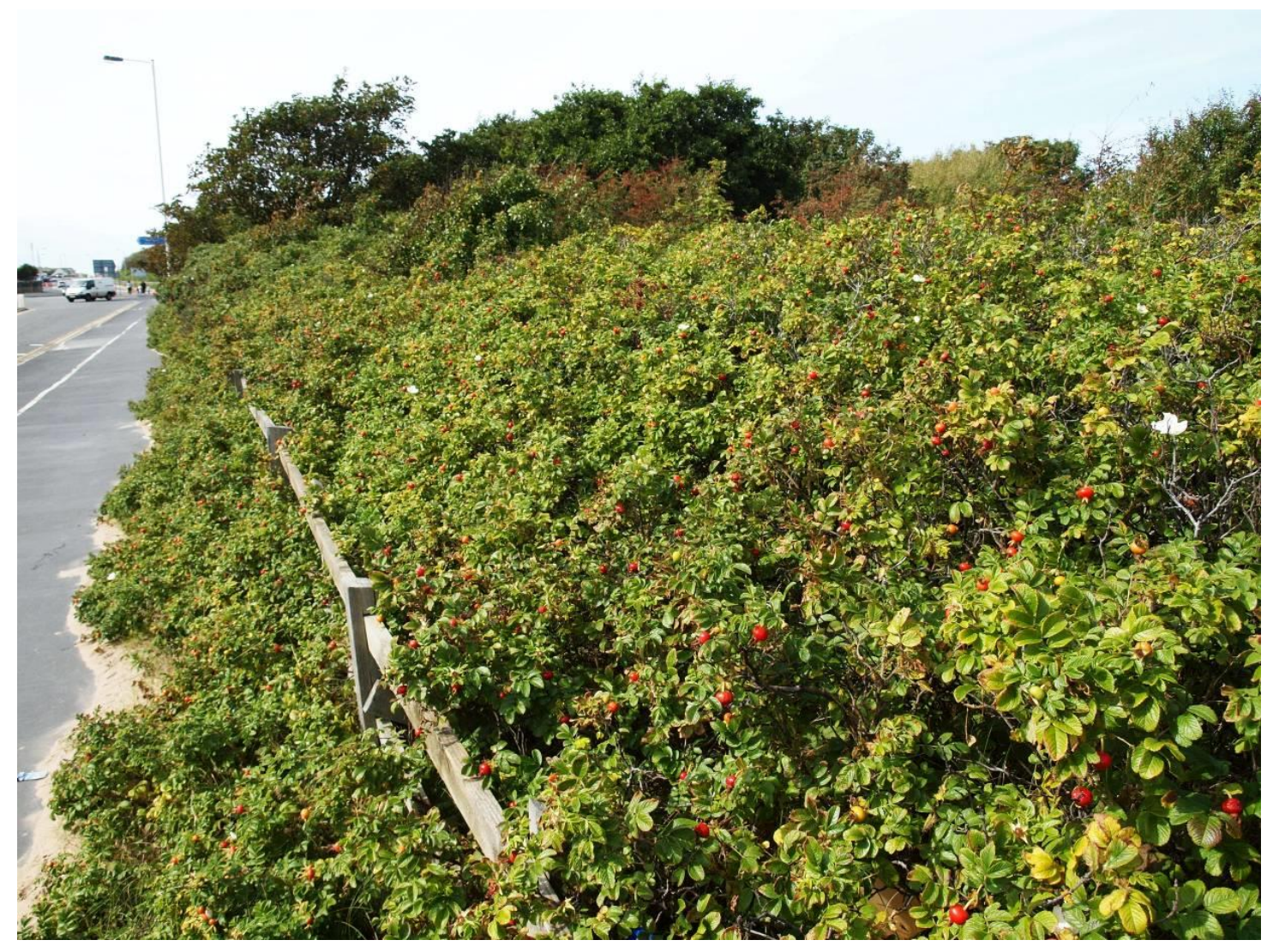

Figure 9. Large patch of R. rugosa at Shore Road, Ainsdale, August 2014

Having an Ellenberg F value of $3, R$. rugosa is regarded as a dry-site indicator (Hill et al., 2004). However, the presence of numerous patches associated with Alnus seepage zones on the eastern edge of Birkdale Green Beach shows that the plant can tolerate occasional water-logging.

Our soil pH data are similar to those cited by Millington et al. (2010) for relatively dry calcareous dune habitats on the Sefton Coast: 7.7 for mobile dunes; 6.4 for fixed dunes. Bruun (2005) quotes soil pH values of 5.7 to 7.6 (median 6.4) in top-soil and 5.4-8.5 (median 6.9) in lower soil horizons for the native range of $R$. rugosa in Japan, these being comparable to, though a little lower than, the Sefton results. However, German studies (Isermann, 2008) report soil pH of 3.5-6.4 (mean 5.1) for stands of $R$. rugosa, while values of 4.77.7 were obtained in Denmark (Bruun, 2005), these being generally lower than the Japanese data. The range of soil $\mathrm{pH}$ values recorded in Sefton is closer to those quoted for Japan than for continental Europe. The trend of lower $\mathrm{pH}$ values further from the coast is attributed to leaching of the initially high calcium carbonate content of the sand over time. Thus, Salisbury (1925) estimated that it took about 200 years for the $\mathrm{pH}$ of soils on the "Southport dunes" to fall from about 8.2 at the top of the beach to 6.4 on the fixed dunes.

Jørgensen and Kollmann (2009) considered that patch size was related to age. They also found some of the largest patches near to villages. Several of the 
large patches, for example at Ainsdale and Birkdale, are known to date back to at least the 1970s (personal observations). Using GIS and field survey, Boardman \& Smith (2016) reported that a sample of large $R$. rugosa patches at Birkdale grew at an average rate of $22 \%$ per annum over a period of 24 years, i.e. doubling every 4-5 years. This compares with estimated annual growth rates of $12-27 \%$ recorded by Jørgensen and Kollmannn (2009) and $16.4 \%$ by Kollmann et al. (2009) in Denmark.

\section{Implications for management}

Weidema (2006) recommended "prevention" by not including $R$. rugosa in planting schemes, especially near the coast. She also emphasised the importance of action in the early stages of establishment to prevent rapid spread, the need for a long-term commitment to control and a strategic approach over a wide area. Once the shrub is well established, the public may perceive it as an attractive component of the landscape and react adversely to its removal for conservation of native species. In Britain, $R$. rugosa is still widely advertised and sold on the internet and through garden centres, though the plant is listed under schedule 9 of the Wildlife \& Countryside Act 1981 (as amended), making it an offence to plant or otherwise allow this species to grow in the wild.

Several techniques have been employed to control or eradicate $R$. rugosa on sand dunes, including digging up patches, cutting or mowing, grazing by livestock and herbicide treatment. Burning is ineffective. For example, there is no evidence that any plants were killed by a large fire at Altcar Training Camp in July 2018 (J. A. Houston, personal communication, 2018). Isermann et al. (2014) report that the most effective control method for large areas is mechanical removal, followed by burning or deep burial of material. Annual follow-up was necessary for up to five years to deal with re-growth. Small bushes could be dug out manually with similar follow-up treatment. Year-round grazing with sheep or "robust" cattle gave good results after five years, while cutting/mowing up to five times per annum was required for up to ten years. Spraying (with Glyphosate) up to four times a year for five years was usually successful but was not recommended due to the possibility of environmental contamination. Thus, depending on formulation, Glyphosate is classed as moderately to highly toxic to amphibians (Govindarajula, 2008). The importance of the Sefton Coast for Natterjack Toads (Epidalea calamita) (Smith \& Skelcher, 2019) means that uses of this chemical should be restricted.

Based on these recommendations, control of $R$. rugosa on the Sefton dunes commenced in 2017 with excavation and deep burial of several patches on Cabin Hill NNR organised by Natural England and the Gems in the Dunes project. This was followed by similar work to deal with the severe infestation on the frontal dunes at Altcar Training Camp, funded jointly by Gems in the Dunes and the Defence Infrastructure Organisation. By late 2018, a 900 m length of frontal dunes had been cleared using heavy machinery. The work at Altcar will continue in 2019, a coastwide programme of $R$. rugosa removal being supported between 
2019 and 2023 by the Dynamic Dunescapes LIFE project coordinated by Natural England.

\section{Acknowledgements}

This project would not have possible without the efforts of the volunteer surveyors: Barbara Allen, Katherine Allen, Joe Barnes, Claire Boardman, Susan Bowden, Mike Brown, Richard Burkmar, Margaret Connor, Lynsey Crellin, Chris Dalzeil, John Dalzeil, Sally Edmondson, David Flynn, Peter Gateley, Val Gateley, Peter Gawthorne, Helen Greaves, Elspeth Green, Howard Harris, John Houston, David Jarvis, Joyce Jarvis, Cathy Jones, Bob Jude, Norma Jude, Paula Kelly, Rosalind King, Patricia Lockwood, Iain Mackennon, Tom Marshall, Jasmine Morgan, Ron Moyes, Emma O'Leary, Peter Olson, Rachael Parks, Stefanie Pearce, Alex Pigott, Bruno Sampaio, Elizabeth Seal, Matthew Spencer, A. Thompson, Don Thompson, Richard Walker, Matt Wiggins and Brian Wilby,

We are grateful to Dr Maike Isermann for helpful information, references and control suggestions. Dave Earl kindly provided information from the draft New Flora of South Lancashire, while land-owners and managers gave permission for the survey on their coastal properties. John Houston provided details of control work at Altcar Training Camp.

\section{References}

Boardman, C. \& Smith, P.H. 2016. Rates of spread of Rosa rugosa (Japanese Rose) determined by GIS on a coastal sand-dune system in Northwest England. Journal of Coastal Conservation, 20: 281-287.

Bruun, H.H. 2005. Rosa rugosa Thunb. Ex Murray. Journal of Ecology, 93: 441470.

Edmondson, S.E. (2010). Non-native plants on the Sefton Coast sand-dunes. In Worsley, A.T., Lymbery, G., Holden V.J.C. \& Newton, M. eds. Seftor's Dynamic Coast, 201-213. Southport: Sefton Technical Services Department.

Edmondson, S.E., Gateley, P.S. \& Nissenbaum, D.A. 1988/89. National

Sand Dune Vegetation Survey: the Sefton Coast. Report no. 917. Peterborough: Nature Conservancy Council.

Gateley, P.S. \& Michell, P.E. 2004. Sand Dune Survey of the Sefton Coast. Report by TEP, Warrington to Sefton Metropolitan Borough Council, Bootle.

Govindarajula, P.P. 2008. Literature review of the impacts of Glyphosate herbicide on amphibians: What risks can the silvicultural use of this herbicide pose from amphibians in B.C.? British Columbia Ministry of Environment, Victoria, B.C. wildlife report no. R-28 [online]. [Accessed 8 March 2013]. Available at: <http://www.env.gov.bc.ca/wld/>.

Green, C.T. 1933. The flora of the Liverpool district. Arbroath: Buncle \& co. Hill, M.O., Preston, C.D. \& Roy, D.B. 2004. PLANTATT. Attributes of British and Irish plants. status, size, life history, geography and habitats. Cambridge: Centre for Ecology \& Hydrology, Monks Wood. 
Hill, N., Beveridge, L., Flynn, A. \& Garbary, D.J. 2010. Rosa rugosa as an invader of coastal sand dunes of Cape Breton Island and mainland of Nova Scotia. The Canadian Field Naturalist, 124: 151-158.

Isermann, M. 2008. Classification and habitat characteristics of plant communities invaded by the non-native Rosa rugosa Thunb. In NW Europe. Phytocoenologia 38: 133-150.

Isermann M., Adriaens, T., Artmann, K., Bele, B., Bengtsson, O., Boesen, M., Burkhard, B., Buttenschøn, R.M., Fløistad, I.S., Grell, H., Grenne, S., Hammeken, K., Hoffmann, H., Jørgensen, H.H., Kiehl, K., Kobarg, N., Labuz, T., Lehtomaa, L., Ludwig, M., Kollmann, J., Leeten, M., Mansen, W., Nilsen, L.S., Provoost, S., Tschöpe, O., Ravn, H.P., Räikkönen, N., Ryttäri, T., Schimansky, P., Schmidt, S., Schulze Dieckhoff., M, Struyve, T., Dijck, D. van, Waldeck, J., Wietjes, H. \& Wittefeld, M. 2014. Best practice in management of Rosa rugosa, 179-181. NEOBIOTA. $8^{\text {th }}$ international conference on biological invasions. Antalya, Turkey.

Jørgensen, R.H. \& Kollmann, J. 2009. Invasion of coastal dunes by the alien shrub Rosa rugosa is associated with roads, tracks and houses. Flora, 204: 289-297.

Kollmann, J., Jørgensen, R.H., Roelsgaard, J. \& Skove-Petersen, H. 2009. Establishment and clonal spread of the alien shrub Rosa rugosa in coastal dunes. A method for reconstructing and predicting invasion patters. Landscape and urban planning, 93: 194-200.

Maskew, R. 2002. Rosa rugosa Japanese Rose. In: C.D. Preston, D.A. Pearman \& T.D. Dines eds. New atlas of the British and Irish flora, 346. Oxford: Oxford University Press.

Millington, J.A., Booth, C.A., Fullen, M.A., Trueman, I.C. \& Worsley, A.T. 2010. Distinguishing dune environments based on topsoil characteristics: a case study on the Sefton Coast. In: Worsley, A.T., Lymbery, G., Holden V.J.C. \& Newton, M. eds. Sefton's dynamic coast, 116-130. Southport: Sefton Technical Services Department.

Salisbury, E.J. 1925. Note on the edaphic succession in some dune soils with special reference to the time factor. Journal of Ecology, 13: 322-328.

Savidge, J.P., Heywood, V.H. \& Gordon, V. eds. 1963. Travis's flora of South Lancashire. Liverpool: Liverpool Botanical Society.

Smith, P.H. 2007. The Birkdale Green Beach - a sand-dune biodiversity hotspot. British Wildlife, 19: 11-16.

Smith, P.H. 2009. The sands of time revisited: an introduction to the sand-dunes of the Sefton coast. Stroud: Amberley Publishing.

Smith, P.H. 2010. The Hall Road-Hightown shingle beach. In: Worsley, A.T., Lymbery, G., Holden V.J.C. \& Newton, M. eds. Seftor's dynamic coast, 258262. Southport: Sefton Technical Services Department.

Smith, P.H. \& Skelcher, G. 2019. Effects of environmental factors and conservation measures on a sand-dune population of the natterjack toad 
(Epidalea calamita) in northwest England - a 31-year study. Herpetological Journal, 29: 146-154.

Weidema, I. 2006. NOBANIS-invasive alien species fact sheet-Rosa rugosa [online]. [Accessed 10 March 2013]. Available at: <www.nobanis.org>.

Copyright retained by author(s). Published by BSBI under the terms of the Creative Commons Attribution 4.0 International Public License.

ISSN: $2632-4970$

https://doi.org/10.33928/bib.2019.01.185 